\title{
Larval dispersal model of coral Acropora in the Karimunjawa Waters, Indonesia
}

\author{
ELIS INDRAYANTI ${ }^{1, \boldsymbol{v}}$, MUHAMMAD ZAINURI ${ }^{2}$, AGUS SABDONO ${ }^{2}$, DIAH PERMATA WIJAYANTI ${ }^{2}$, \\ WIDODO SETIYO PRANOWO ${ }^{3}$, HENDRY SYAHPUTRA ROPINUS SIAGIAN ${ }^{2}$ \\ ${ }^{1}$ Coastal Resources Management Doctoral Program, Faculty of Fisheries and Marine Sciences, Universitas Diponegoro. Jl. Prof. Soedarto, SH. \\ Tembalang, 50725, Semarang, Central Java, Indonesia. Tel./fax.: +62-298-7474698, `email: elisindrayanti@yahoo.com \\ ${ }^{2}$ Faculty of Fisheries and Marine Sciences, , Universitas Diponegoro. J1. Prof. Soedarto, SH. Tembalang, Semarang 50725, Central Java, Indonesia. \\ ${ }^{3}$ Marine and Coastal Data Laboratory, Marine Research Center, Indonesian Ministry of Marine Affairs and Fisheries. Jl. Pasir Putih II No. 636-694, \\ Ancol Timur, Jakarta Utara 14430, Jakarta, Indonesia
}

Manuscript received: 11 June 2019. Revision accepted: 30 June 2019.

\begin{abstract}
Indrayanti E, Zainuri M, Sabdono A, Wijayanti DP, Pranowo WS, Siagian HSR. 2019. Larval dispersal model of coral Acropora in the Karimunjawa Waters, Indonesia. Biodiversitas 20: 2068-2075. Identification of connectivity patterns through the larval dispersal dynamics is urgently needed to support the sustainable larval supply. Many studies on the larval coral distribution have been reported. However, no study of coral larval dispersal has been conducted in Karimunjawa. The purpose of this research was to build a model of coral larval dispersal in Karimunjawa waters. Modeling was carried out by using a 2-dimensional hydrodynamic current approach with a particle tracking module. The larval release was conducted during the full moon in the first transition period (April) and the second transition period (October). The larval source was assumed from around Sambangan waters. Modeling validation was done by comparing the model results to the direct of current measurements with Acoustic Doppler Current Profiler (ADCP). The results of larval dispersal model showed that both the transition seasons I and II were similar in the direction of movement towards the west. This result indicated that currents, tides, and winds influenced the larval dispersal process. Also, the model results showed that Sambangan, Tengah, Cilik, Sintok, the west site of Karimun, Menjangan Kecil, and Menjangan Besar Islands were identified as the location of the larval settlement.
\end{abstract}

Keywords: Connectivity, coral larvae, Karimunjawa, larval dispersal, numeric model

\section{INTRODUCTION}

Karimunjawa archipelago, consists of 27 islands, is located in the Java Sea. This archipelago was designated as a marine reserve area through the Minister of Forestry Decree No. 123 / Kpts-II / 1986 on April 9, 1986. Based on Minister of Forestry Decree No. 78 / Kpts-II / 1999 dated February 22, 1999, Karimunjawa's status changed to Karimunjawa National Park (KNP). This park includes marine and terrestrial components with specifically 1101 $\mathrm{km}^{2}$ of the sea, $13 \mathrm{~km}^{2}$ of tropical lowland forest and $3 \mathrm{~km}^{2}$ of mangrove forests. KNP is one of the first maritime areas that recognized as a marine biodiversity conservation area in Indonesia (Nababan et al. 2010; Campbell et al. 2013).

Coral reef ecosystem of Karimunjawa is approximately 713,11 hectares that consist of 69 scleractinian genera. These genera are dominated by genus Acropora and Porites (Nababan et al. 2010). In this study, Acropora was chosen as subject research due to a dominant role in species composition and abundance of many Indonesian coral ecosystems (Suharsono 2008). Acroporid is an excellent example of studying reef connectivity because they have much genetic information available for all coral genes throughout the world. Moreover, this genus has a more extensive geographical range compared to other coral families (Ladner and Palumbi 2012). Reproductive activities of 21 Acropora species in the Karimunjawa islands had been observed for five consecutive years (20082012) (Wijayanti et al. 2019). The observations showed that multi-specific spawning occurred during the first transition period and the second transition period (Permata et al. 2012; Wijayanti et al. 2019). Furthermore, DKP Central Java (2016) reported that Sambangan, Genting, and Seruni Islands of Karimunjawa were identified as excellent larval sources due to their high coral cover $(>50 \%)$.

Coral larvae are simple, uniform ciliates and limited mobility that swim at speeds less than $0.4 \mathrm{~cm} \mathrm{~s}^{-1}$. They are highly dependent on ocean currents for their dispersal and distribution (Gleason et al. 2009; Hata et al. 2017). The wide-ranging study area, the length of time required for observation and insufficient means of transportation were obstacles during conducting of this research. Therefore, hydrodynamic modeling of current flow and particle tracking could be used to predict larval routes and attachment patterns (Siegel et al. 2003; Wood et al. 2014; Fitriadi et al. 2017; Storlazzi et al. 2017). This approach was used as a basis for the assumption that coral larvae were in the planktonic phase. In this phase, coral larvae are particles that float, neutral, and passively carried by the mass of water. The larvae can spread several kilometers until they find a suitable place to attach (Siegel et al. 2003; Tay et al. 2012; Wood et al. 2014).

A better understanding on the period and larval dispersal pattern in the conservation area will increase the 
understanding of recruitment and connectivity among reefs (Kool and Nichol 2015; van der Meer et al. 2015; Storlazzi et al. 2017). Then, the research on modeling of larval dispersal is urgently needed to be conducted. The study results are expected to contribute to an understanding of local population dynamics and determining the coral reef conservation strategy in Karimunjawa. The coral larval dispersal is influenced by the number of gametes released, the success of fertilization and mortality (Tay et al. 2012). The mortality was assumed to be zero in the simulation model due to unavailable mortality data in Karimunjawa. However, the validation of the current hydrodynamic model showed good correspondence between the model and the in situ data, and this model indicated that the island identified as a larval settlement area showed a high coral cover and a relatively close genetic relationship (Wijayanti et al. 2018).

\section{MATERIALS AND METHODS}

\section{Study area and model domain}

The study was conducted in Karimunjawa Islands in 2018 which is located about 45 nautical miles or $83 \mathrm{~km}$ northwest of the city of Jepara, Central Java $\left(5^{0} 40\right.$ ' $-5^{0} 57^{\prime}$ LS; 110.04-110.40 BT) (Figure 1). Karimunjawa is located in the Java Sea, which is categorized as shallow waters. Its current circulation pattern is influenced by monsoons, that cause Karimunjawa to experience four distinct seasons (Tomascik et al. 1997). The seasons are the southwestern season (November-February); northeastern season (MayAugust); the first transition period (March-April); and the second transition period (September-October). These seasons greatly influence the properties of the Karimunjawa waters, such as ocean currents flowing from west to east (southwest monsoon). This season is characterized by high wind speed and high ocean waves.
On the contrary, ocean currents that flow from east to west (east season), is characterized by low wind speed and low ocean waves (Balitbang Jateng 2003). Research showed that the wind direction comes from the southeast and moves the current to the west, with higher wind speed in the second transition period compared to the first transition period.

Initial release locations are coral reefs around Sambangan, Genting, and Seruni islands, with live coral cover $\geq 50 \%$ (DKP Central Java 2016). The eight-point locations of the coral larval sources represent Sambangan compass points can be seen in Table 1 and Figure 1.

The model domain consists of large and small domains. The large model domain covers the Karimunjawa waters with $34 \mathrm{~km} \mathrm{x} 17 \mathrm{~km}$ areas and the maximum size of $100,000 \mathrm{~m}^{2}$ element area with the smallest angle of $30^{\circ}$ (Figure 2a). The small model domain assumed to be the source area of larvae that covers the waters around Sambangan, Genting and Seruni Islands with a maximum element area of $10 \mathrm{~m}^{2}$, the smallest angle of $30^{\circ}$ and $5 \mathrm{~m}$ mesh size (Figure 2b). The triangular mesh was used as a design model with a higher resolution in the larval source area.

Table 1.. The 8 locations of the coral larval sources that represent around Sambangan compass point

\begin{tabular}{lcc}
\hline \multicolumn{1}{c}{ Source } & Longitude & Latitude \\
\hline North source (N) & 110.5849 & -5.8420 \\
Northeast source (NE) & 110.5901 & -5.8420 \\
East source (E) & 110.5881 & -5.8460 \\
Southeast source (SE) & 110.5860 & -5.8474 \\
South source (S) & 110.5849 & -5.8480 \\
Southwest source (SW) & 110.5801 & -5.8495 \\
West source (W) & 110.5787 & -5.8459 \\
Northwest source (NW) & 110.5805 & -5.8428 \\
\hline
\end{tabular}

Table 2. Data and coefficient used in the model

\begin{tabular}{|c|c|c|}
\hline Data/ coefficient & Source & Information \\
\hline Bathymetric data & $\begin{array}{l}\text { Indonesian map, Java North Coast, Karimunjawa } \\
\text { Islands, Central Java, from the Navy's Hydro- } \\
\text { oseanography Service (2013) }\end{array}$ & $\begin{array}{l}\text { Scale 1: } 75000 . \text { Bathymetric data is recorded as } \\
\text { an input model with the format. XYZ }\end{array}$ \\
\hline $\begin{array}{l}\text { Tidal data (open boundaries } \\
\text { conditions) }\end{array}$ & MIKE Prediction (Global Tide Model) & $\begin{array}{l}\text { The provided elevation data is one year with } 1 \text { - } \\
\text { hour intervals, i.e., from January 1, 2018, to } \\
\text { December } 31,2018 \text {, starting at } 00.00\end{array}$ \\
\hline Wind data (friction condition) & $\begin{array}{l}\text { Wind data obtained from } \\
\text { http://ogimet.org }\end{array}$ & $\begin{array}{l}\text { The one-year representative data with a } 3 \mathrm{~h} \\
\text { time interval, and the soft start interval in the } \\
\text { model area is } 600 \mathrm{sec} \text {. }\end{array}$ \\
\hline Time step & $600 \mathrm{~s}$ & \\
\hline Number of time step & 4319 & \\
\hline Wind friction & 0.0025 & Varying in time, constant in domain \\
\hline Initial surface level & $0.3 \mathrm{~m}$ & \\
\hline Horizontal eddy viscosity & Smagorinsky formula 0.28 & \\
\hline Bed resistance & Chezy number 38 & \\
\hline
\end{tabular}



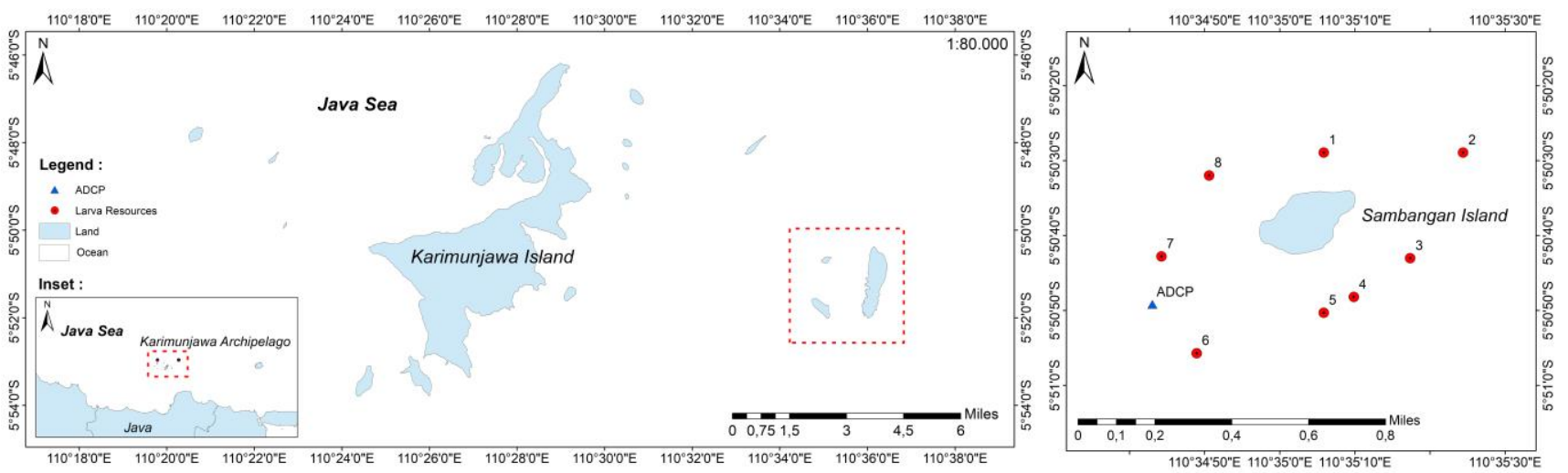

Figure 1. Map of the study area in Karimunjawa, including Sambangan Island that was selected as coral larval source for the model

A
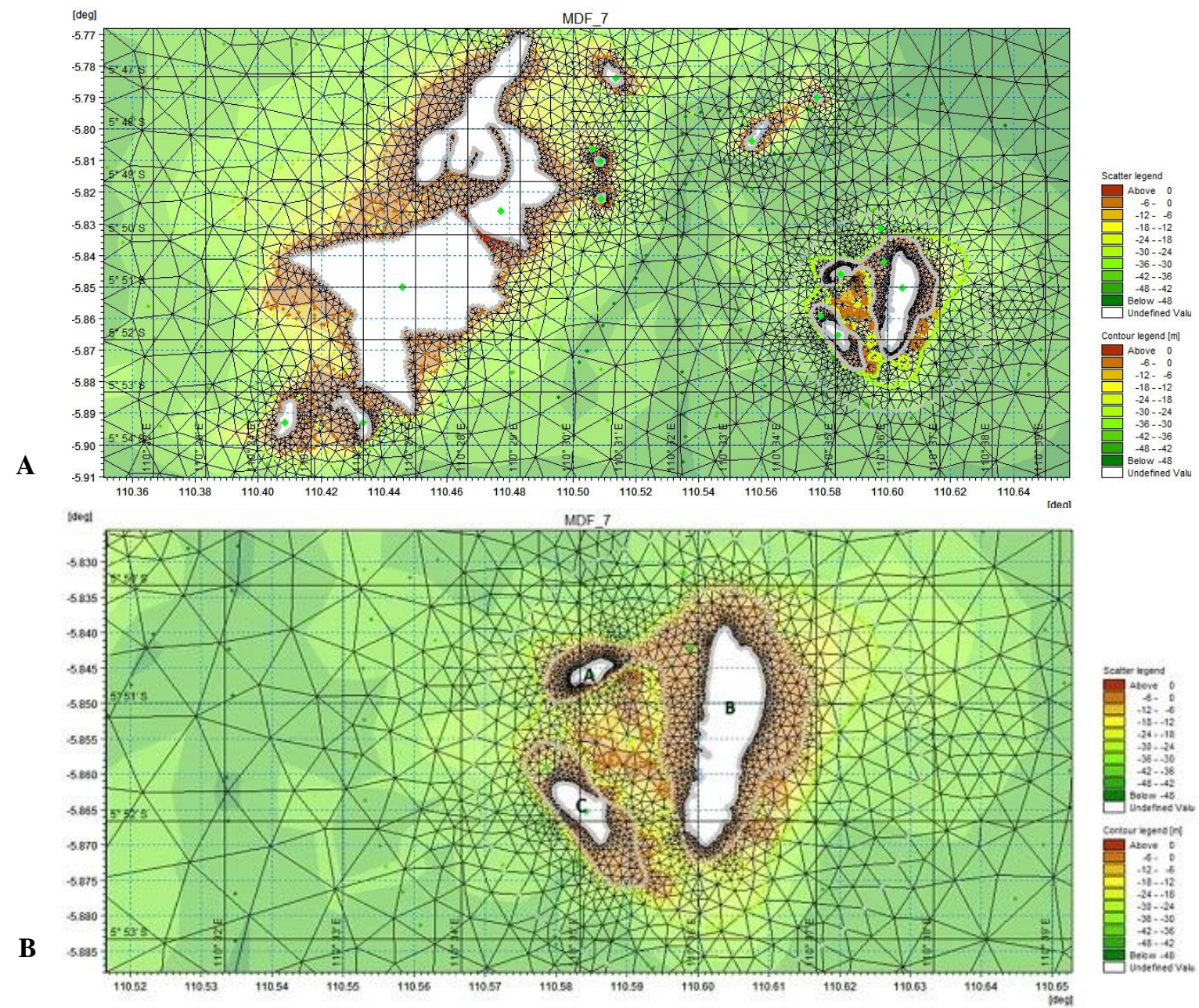

Figure 2. A. The large model domain of Karimunjawa waters with triangular mesh. B. The small model domain of Sambangan (A), Genting (B), and Seruni Islands (C) with triangular mesh

\section{Current model}

The initial model to create larval coral dispersal was the Current Surface model. The Current Surface model was established by using a numerical model (MIKE 21) developed by the Danish Hydraulics Institute (DHI: www.mikepoweredbydhi.com). The equations used in this model included continuity equations and momentum equations (DHI 2012). This model has been used to track of coral larvae in Singapore (Tay et al. 2012), Kapoposang Marine Tourism Park, Indonesia (Afandy et al. 2017). Data input and coefficients used in this model were presented in Table 2. 


\section{Model validation}

Validation was conducted to find out whether the model results were close to the actual measurement values in the field. Validation was carried out by comparing the water surface elevation of the modeling results with direct measurement results using Acoustic Doppler Current Profiler (ADCP), which was placed in the Sambangan waters at the coordinates of-5.8477 ${ }^{\circ} \mathrm{S}$ and $110,5784{ }^{\circ} \mathrm{E}$ (Figure 1). Observation of measurements was carried out for $7 \times 24$ hour (July, 14 to 21, 2018) with average time interval of $600 \mathrm{~s}$ and a sample rate of $300 \mathrm{~s}$. The current velocity was measured at 6 depth layers $(2 \mathrm{~m}, 4 \mathrm{~m}, 6 \mathrm{~m}, 8$ $\mathrm{m}, 10 \mathrm{~m}, 12 \mathrm{~m}$ ) with a total depth of ADCP was $14 \mathrm{~m}$.

\section{Larval dispersal model}

The larval dispersal model was constructed by using the Particle-Tracking module in the MIKE 21 FM application (Flow Model). This module calculates the displacement of the particle position from the input speed of the hydrodynamic model output every time (DHI 2012). The Acropora larvae were used as the object research due to their dominance and the main component of reef builders in Karimunjawa (Nababan et al. 2010). Also, this coral genera spawning time was already known two times a year (Permata et al. 2012; Wijayanti et al. 2019). The larval dispersal corals was a complex process that involves external and internal factors.

Furthermore, there were limited information in the behavior and characteristics of coral larvae. Therefore, several assumptions were used in the model construction, such as:

i. Coral larvae are considered as particles that do not have a swimming force, so the particle swimming speed is not significant compared to the current (Tay et al. 2012; Hata et al. 2017).

ii. Spawning coral pattern in Karimunjawa likely follow the lunar cycle, split spawning occurred over an extended period, ranging from 8 days before full moon to 9 days after full moon in March 2009 and 7 days before full moon and 1 day after full moon in April 2012, 1 day before full moon and 2 days after full moon in October 2012 (Permata et al. 2012; Wijayanti et al. 2019). Based on the previous research, release time was assumed with 2 scenarios of release duration: the first transition period (time release April 12, 2018, 20:00 WIB) and the second transition period (time release 16 October 2018, 00:00 WIB).

iii. The density of larval number released at the spawning time was adjusted to the proportion of coral reef conditions at the source location. This study did not attempt to make a model of the real number larval deployment. Whereas, this study was focused on the representation of the spatial larval dispersal potency and the connectivity levels among locations

iv. In this study, the life duration of coral larvae was 19 days. Pelagic larval duration (PLD) varies in each coral species, for example in a short time between 4-7 days, medium about 30 days and length $>100$ days (Treml et al. 2008; Kool et al. 2011; Tay et al. 2012;
Schill et al. 2015).

v. The movement of these particles was a conservative movement, where decay, erosion, and sediment velocity values were ignored. During the simulation, it assumed that there was no predation and death process for larvae (Sundelöf and Jonsson 2012; Tay et al. 2012).

vi. Model simulation results were presented on a time scale as long as the larval pelagic state moves in the sea. The coral larval movement was represented by the total of mass particles. The larval movement was divided into three stages, namely, the initial stage when the coral start spawning on April 12, 2018 (first transition period) and October 16, 2018 (second transition period); the medium stage occurred when the larvae entered the pelagic stage on April 16, 2018 (first transition period) and October 23, 2018 (second transition period); and the final stage occurred before the end of the larval phase on April 24, 2018 (first transition period) and October 28, 2018 (second transition period).

\section{RESULTS AND DISCUSSION}

\section{Hydrodynamic condition of Karimunjawa Island}

The sea currents movement of Karimunjawa island is influenced by the tidal movement. The direction of sea currents in Karimunjawa Archipelago is bi-directional current which has two directions, east, and west-southwest. A range of velocity of sea currents are between 0.01-0.20 $\mathrm{m} / \mathrm{s}$ in the first transition period (April) and a range is between $0.05-0.35 \mathrm{~m} / \mathrm{s}$ in the second transition period (October). The tides off Karimunjawa Islands are mixed tide prevailing semidiurnal type with the Formzahl value is 2.89. Karimunjawa Islands have varying wind speed, and the direction of wind is predominantly from southeast, east and north, with higher wind speed in the second transition period (a range of speed between 1.0-7.9 m/s) compared to the first transition period $(1.0-3.3 \mathrm{~m} / \mathrm{s})$.

The validation of model results showed that the water surface elevation of the modeling results and direct observation was similar (Figure 3). Also, the calculation result of tidal constituents was $88.5 \%$ of the correction value. Validation results indicated that the model results were close to the field measurement results.

\section{Coral larvae dispersal model \\ The transition period}

The dispersion of coral larvae on Karimunjawa Island was represented by the total of a mass particle in the first transition period and the second transition period can be seen in Figure 4. In the first transition (April 2018), coral larvae in the initial stages moved towards the west of Sambangan Island with a total mass approximately at 100 $\mu \mathrm{g} / \mathrm{m}^{3}$. After 12 hours the movement continues to the west with a total mass of $70 \mu \mathrm{g} / \mathrm{m}^{3}$. In the medium stage, the total mass of larvae began to spread increasingly extending towards the west and the south to Tanjung Batulawang with a concentration of $0.14 \mu \mathrm{g} / \mathrm{m}^{3}$, and Kemujan with a total mass of $0.07 \mu \mathrm{g} / \mathrm{m}^{3}$. 


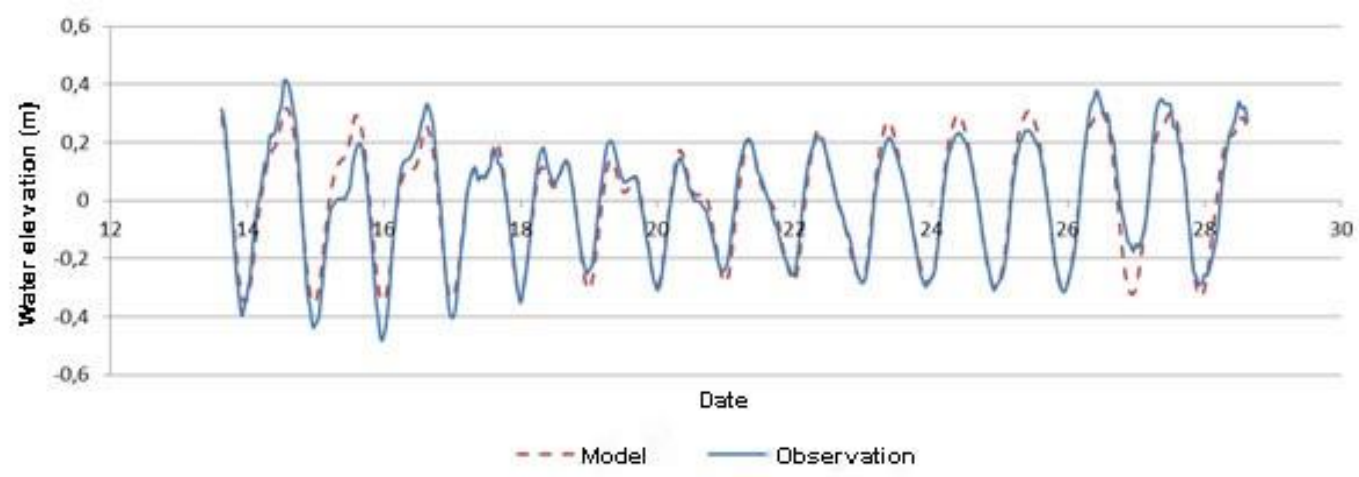

Figure 3. The validation of model by comparing the water surface elevation of the modeling results with direct measurement

Transition I

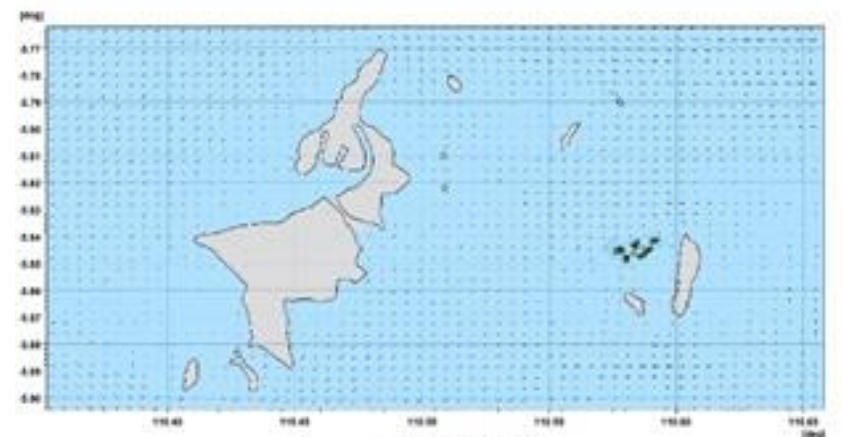

A. April 12, 2018

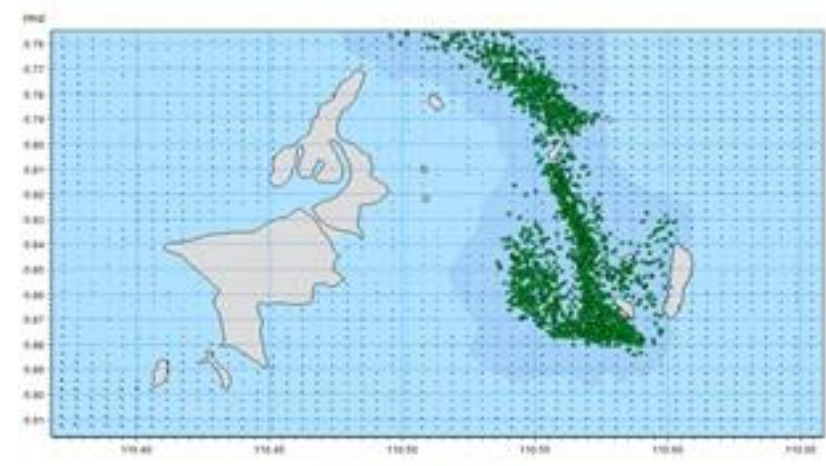

B. April 16, 2018

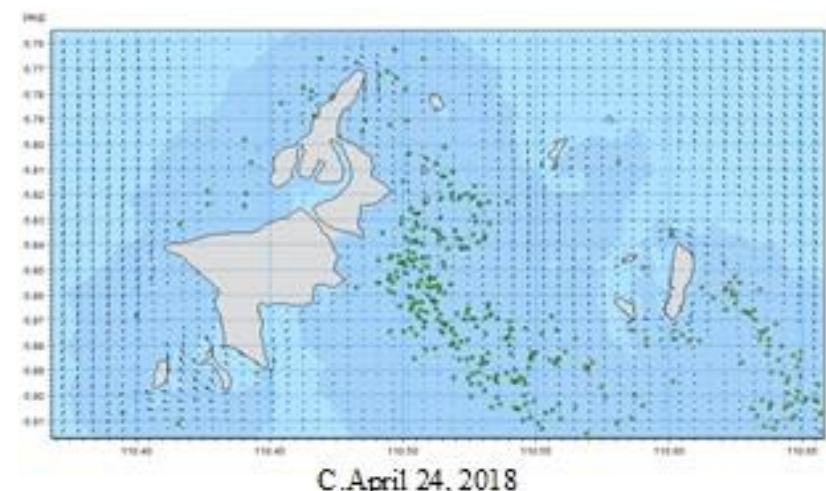

Transition II

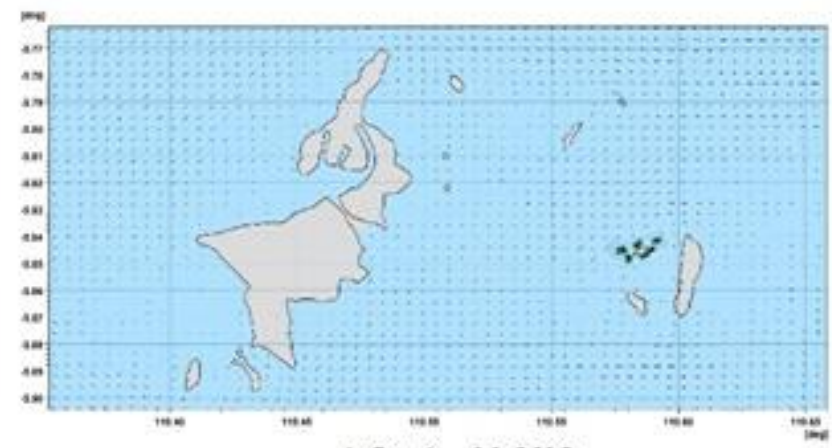

A. October 16,2018

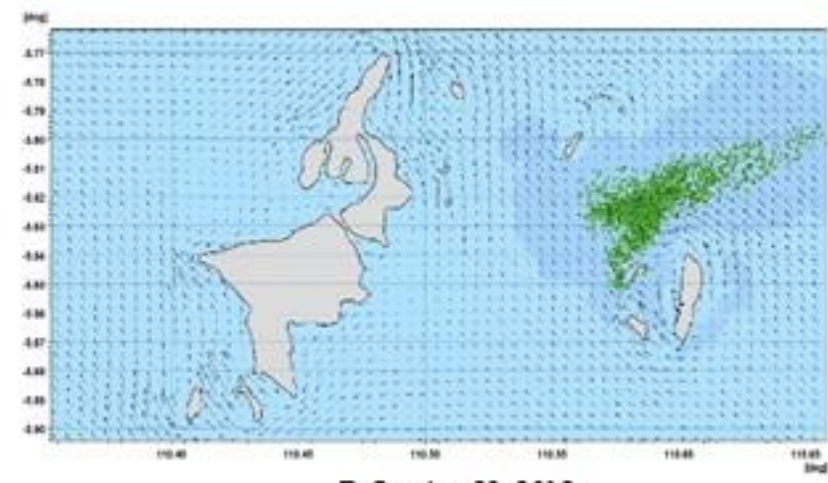

B. October 23,2018

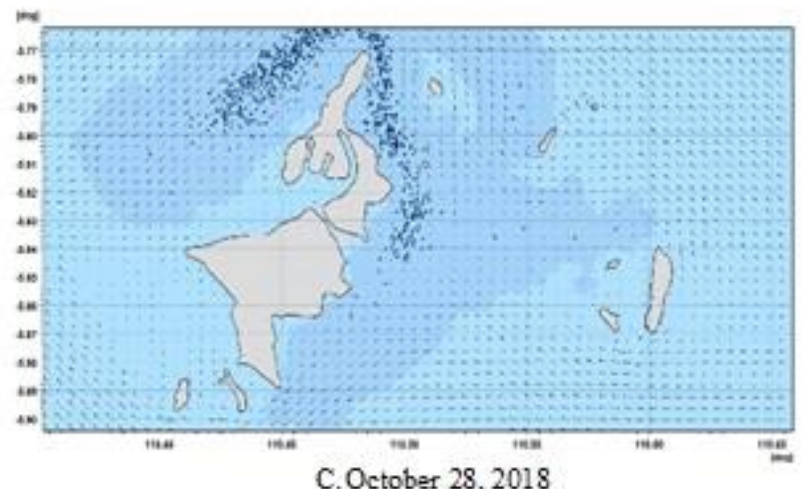

Figure 4. The coral larval dispersal model in Karimunjawa in the first transition period (April) and the second transition period (October) was displayed in 3 stages which represent (A) the initial stages (coral release egg or coral spawning), (B) the medium (coral larval entered their pelagic stage) and (C) before the end of the larval phase 


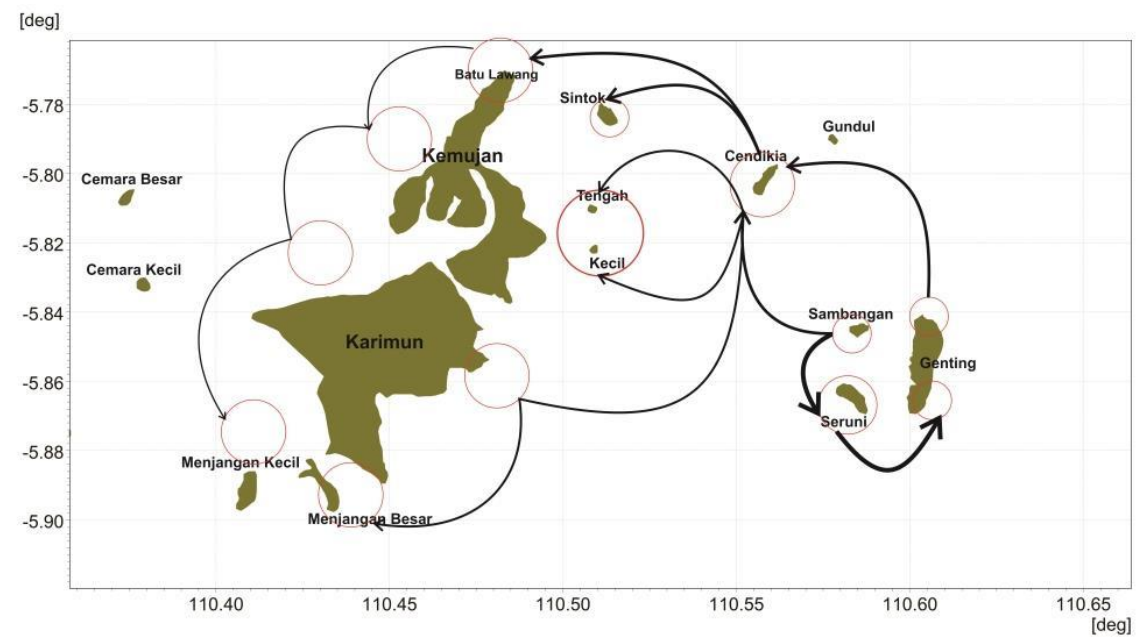

Figure 5. The areas were identified as the location of the larval settlement in the first transition period. Coral larvae originated from Sambangan waters spread around Sambangan, Genting and Seruni Islands. The larvae moved to the north towards the waters around Cilik, Tengah, Sintok, Tanjung Batulawang, and Kemujan Islands. The small portion of the larvae moved to the south through the eastern side of Karimun Island. The larval movement in the final stage moved to the west side of Karimun, Menjangan Kecil and Menjangan Besar

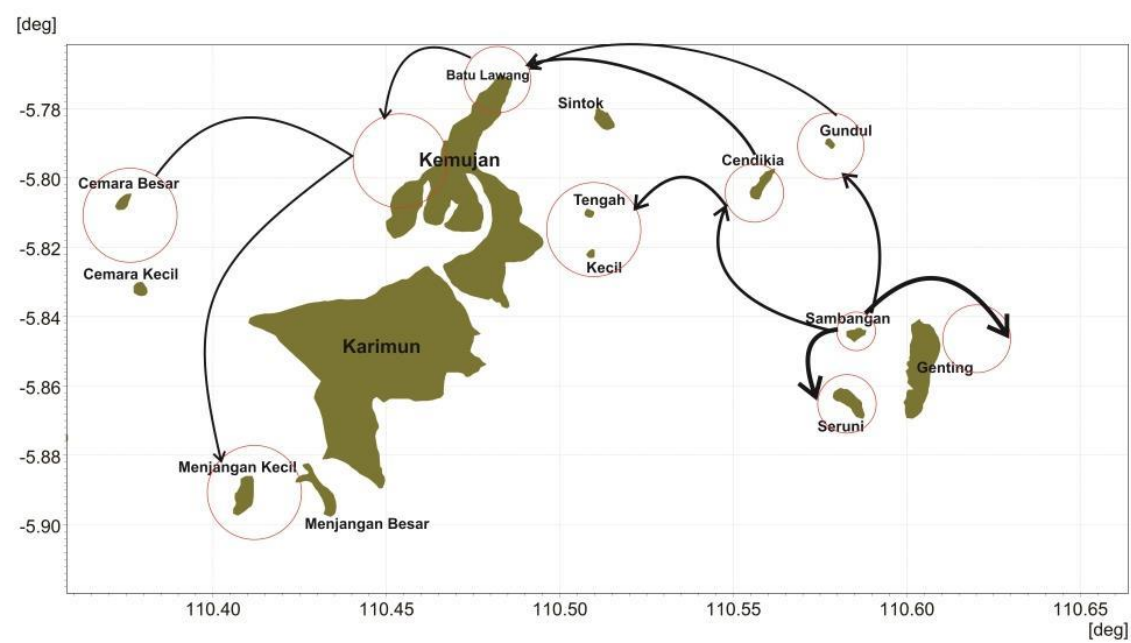

Figure 6. The areas were identified as the location of the larval settlement in the second transition period. Coral larvae originated from Sambangan moved towards the northeast and northwestern sides of Sambangan and Genting Islands. The larval movement began to spread into the larger areas, moving towards the north side of Cendikia, Tengah, Cilik, Batu Lawang. At the end of the stage, the larvae moved to the west side of Kemujan, Karimun and Menjangan Kecil Islands

In the second transition period, coral larvae moved from the east to the western area of Sambangan Island with a total mass concentration up to $146 \mu \mathrm{g} / \mathrm{m}^{3}$. In the medium stage, the coral larvae moved towards the northeast, then to the northwest and spread around Cendikia Island, with a total mass concentration between $0.1-2.8 \mu \mathrm{g} / \mathrm{m}^{3}$. In the final phase, the total coral mass decreases in the range between 0.01-1.9 $\mu \mathrm{g} / \mathrm{m}^{3}$, spread over Sintok, Cilik, and Tanjung Batulawang waters. Distribution of coral larvae in the first and second periods showed a decrease in the total mass concentration of coral larvae from the initial to the final stages, presumably while their disperse some larvae have sunk or settled.

The overall movement of coral larvae on Karimunjawa Island can be seen in Figure 4. The first transition period, where larval release around Sambangan waters occurred on April 12, 2018 at 18:00, moving towards the west side of Seruni Island. Following the current movement in the tidal phase, and the current direction was changed, the larvae moved towards the east side of Genting Island and spread in the waters around Sambangan, Genting and Seruni Islands. Furthermore, on April 16, 2018, the larvae moved to the north towards the waters around Cilik, Tengah, Sintok, Tanjung Batulawang, and Kemujan Islands. The 
larval movement in the final stage was on April 24, 2018. The larvae moved to the west side of Kemujan and Karimun Island. The small portion of the larvae moved to the southern regions of Karimun Island through the east side of Karimun.

The second transition period, where the larval release occurred on October 16, 2018, at 00.00. The larvae moved following the current movement that experienced changes in the tidal phase from ebb to high tides. The coral larvae moved towards the northeast and northwestern sides of Sambangan and Genting Island. The next stage of larval dispersal occurred on October 23, 2018. The larval movement began to spread into the larger areas, moving towards the north side of Cendikia waters. The final movement was on October 28, 2018; the larvae moved to Sintok, Cilik and Tengah Islands, to the west side of Karimun and Kemujan Islands.

Based on the result and simulation of coral larval dispersal in April and October 2018, the larval movement pattern can be described and larval settlement location in the first transition period (Figure 5) as well as the second transition period (Figure 6) can be identified.

\section{Discussion}

Distribution of coral larvae in Karimunjawa depends on the current direction, velocity, and flow patterns. The hydro-oceanographic variability is influenced by the monsoon pattern that takes place during the first transition period and the second. Gaonkar et al. (2012) stated that western and eastern monsoons play an important role in the distribution of organisms in the tropics. The larval dispersal model in the first transition period and the second period indicated that the direction of larval movement tends to go to the westward. However, the larval dispersal pattern in the second transition period showed no larval coral disperse through the eastern side of Karimun Island. This result indicated that the distribution of coral larvae in Karimunjawa was influenced by both seasonal wind patterns and tidal currents. Moreover, Karimunjawa has specific geographical characteristics where the region of the water is surrounded by a group of large and small islands. Several previous studies reported that tidal currents in Karimunjawa flow eastward during high tide and flow west or northwest at low tide (BTNKJ 2010).

The farthest distance of larval dispersal in the first transitional period and the second in Karimunjawa were 23.3 and $24.62 \mathrm{~km}$ to the west from larval sources; respectively. Similar results were also reported in Biawak Island (Fitriadi et al. 2017) and the Kapoposang Marine Tourism Park, Sulawesi (Afandy et al. 2017), coral larvae could spread several kilometers until they find a suitable habitat to settle. The distribution of larvae depends on ocean currents, without active swimming simulation or vertical migration (Tay et al. 2012; Wood et al. 2014; Hata et al. 2017).

Some locations such as Sambangan, Tengah, Kecil, Sintok, the west side of Karimun, Menjangan Kecil and Menjangan Besar Islands were identified as a for coral larvae settlement originated from Sambangan island. These results indicated that coral reef existence in Karimunjawa is believed to originate from reef propagules in Karimunjawa itself. This study result is also supported by Wijayanti et al. (2018) stated that DNA analysis carried out on Acropora hyacinthus collected from five islands in Karimunjawa (Seruni, Sambangan, Genting, Cilik and Menjangan Kecil) showed a relatively close genetic relationship.

The coral larval dispersal is influenced by the number of gametes released, the success of fertilization and mortality (Tay et al. 2012). However, the mortality was assumed to be zero in the simulation model due to unavailable mortality data. The mortality of invertebrate larvae depends on many factors such as predation (Baird 2001), water temperature (Nozawa and Harrison 2007), salinity (Vermeij et al. 2006) and sedimentation (Humanes et al. 2017). Consequently, the connectivity among reefs in Karimunjawa was resulting in overestimation. However, the validation of the current hydrodynamic model showed good results, and this model indicated that the island identified as a larval settlement area showed a high coral cover and a relatively close genetic relationship.

The results of this study have important implications for the coral reef management and conservation efforts in Karimunjawa. The islands identified as the larval attachment area and have high coral cover need special attention. Fortunately, the Sambangan waters that were identified as sources of larvae was not the main tourist destination so far. The Sambangan, Genting, and Seruni waters have a substantial live coral cover and can be a robust coral source. A more complex model by extending the scope model, several larval sources, combining hydrodynamic conditions and biological properties of coral larvae might be possible in further studies to find out more about the potential larval coral resources and their connectivity.

In conclusion, the model showed that coral-larval dispersal in the first transition period and the second follows regional current patterns that were influenced by tides and seasonal wind patterns. Coral larvae originated from Sambangan waters were distributed to the west on adjacent islands including Sambangan, Tengah, Cilik, Sintok, west side of Karimun Island, Menjangan Kecil and Menjangan Besar.

\section{ACKNOWLEDGMENTS}

The authors would like to thank Marine Research Center, Indonesian Ministry of Marine Affairs, and Fisheries for MIKE 21 License. Arfiyan, ST from PT. Pura Baruna Lestari, Coral Unit for support during research in Sambangan island. Funding was provided by the Indonesia Directorate General of Higher Education No. 381/SP2H/PP/DP2M/VI/2018 (the year 2018). Research permit was obtained from Karimunjawa National Park Authority under permission number: 1141/T.34 /TU/SIMAKSI/03/2018. We appreciate the reviewer for the time they invested to improve our manuscript. 


\section{REFERENCES}

Afandy Z, Damar A, Agus SB, Wiryawan B. 2017. Coral larval dispersal model on conservation area of Kapoposang Marine Tourism Park. Coast Ocean J 1 (2): 39-51.

Baird AH. 2001. The Ecology of Coral Larvae: Settlement Patterns, Habitat Selection and The Length of the Larval Phase. [Dissertation]. James Cook University, Townsville, Australia.

Balitbang Jateng. 2003. Research on identifying and saving coral reef ecosystem for fisherman in Karimujawa. Balitbang Bapeda Provinsi Jateng. [Indonesian]

BTNKJ (Balai Taman Nasional Karimunjawa). 2010. Coral reef monitoring report. Ministry of Forestry. Director General of Forest Protection and Nature Conservation. Karimunjawa National Park Office. Semarang. [Indonesian]

Campbell SJ, Kartawijaya T, Yulianto I, Prasetia R, Clifton J. 2013. Comanagement approaches and incentives improve management effectiveness in the Karimunjawa National Park, Indonesia. Mar Policy 41: 72-79. DOI: 10.1016/j.marpol.2012.12.022.

Danish Hydraulics Institute (DHI). 2014. MIKE 21 Toolbox

DKP Jateng. 2016. Document of RZWP3K: coastal resources study in order to revise regional regulation (RZWP3K), Central Java province. [Indonesian]

Fitriadi CA, Dhahiyat Y, Purba NP, Harahap SA .2017. Coral larvae spreading based on oceanographic condition in Biawak Islands, West Java, Indonesia. Biodiversitas 18: 681-688.

Gaonkar CA, Samiksha SV, George G, Aboobacker VM, Vethamony P, Anil AC. 2012. Numerical simulations of barnacle larval dispersion coupled with field observations on larval abundance, settlement, and recruitment in a tropical monsoon-influenced the coastal marine environment. J Mar Syst 94: 218-231.

Gleason DF, Danilowicz BS, Nolan CJ .2009. Reefs water stimulates substratum exploration in planulae from brooding Carribean corals. Coral Reefs 28: 549-554.

Hata T, Madin JS, Cumbo RV, Denny M, Figueiredo J, Harii S, Thomas CJ, Baird AH. 2017. Coral larvae are poor swimmers and require fine-scale reef structure to settle. Sci Rep 7: 2249. DOI: 10.1038/s41598-017-02402-y.

Humanes A, Ricardo G, Willis B, Fabricius K, Negri A. 2017. Cumulative effects of suspended sediments, organic nutrients, and temperature stress on early life history stages of the coral Acropora tenuis. Sci Rep 7: 44101. DOI: 10.1038/srep44101.

Kool JT, Paris CB, Barber PH, Cowen, RK. 2011. Connectivity and the development of population genetic structure in Indo-West Pacific coral reef communities. Glob Ecol Biogeogr 20: 695-706.

Kool JT, Nichol SL. 2015. Four-dimensional connectivity modeling with application to Australia's north and northwest marine environments. Environ Model Soft 65: 67-78.

Ladner JT, Palumbi SR. 2012. Extensive sympatry, cryptic diversity and introgression throughout the geographic distribution of two coral species complexes. Mol Ecol 21: 2224-2238. DOI:10.1111/j.1365294X.2012.05528.x.
Nababan MG, Munasik, Yulianto I, Kartawijaya T, Prasetia R, Ardiwijaya RL, Pardede, ST, Sulisyati R, Mulyadi, Saifuddin, Y. 2010. Ecosystem status of Karimunjawa National Park. Wildlife Conservation Society-Indonesia Program, Bogor. [Indonesian]

Nozawa Y, Harrison PL. 2007. Effects of elevated temperature on larval settlement survival in scleractinian corals, Acropora solitaryensis and Favites chinensis. Mar Biol 152: 1181-1185.

Permata DP, Indrayanti E, Haryanti D, Fika L, Arfiyan, Achmad A. 2012. Biannual Multispecific Spawning in Karimunjawa Archipelago, Indonesia. Coral Reefs 31. DOI: 10.1007/s00338-012-0909-9

Schill SR, Raber GT, Roberts JJ, Treml EA, Brenner J, Halpin PN. 2015. No reef is an island: Integrating coral reef connectivity data into the design of regional-scale marine protected area networks. PLoS ONE 10 (12): e0144199.

Siegel DA, Kinlan BP, Gaylord B, Gaines SD. 2003. Lagrangian descriptions of marine larval. Mar Ecol Prog 260: 83-96.

Storlazzi CD, van Ormondt M, Chen Y-L, Elias EPL. 2017. Modeling fine-scale coral larval dispersal and interisland connectivity to help designate mutually-supporting coral reef marine protected areas: insights from Maui Nui, Hawaii. Front Mar Sci 4: 381. DOI: 10.3389/fmars.2017.00381

Suharsono. 2008. Indonesian coral species. LIPI Press, Jakarta. [Indonesian]

Sundelöf A, Jonsson PR. 2012. Larval dispersal and vertical migration behaviour-a simulation study for short dispersal times. Mar Ecol 33: 183-193.

Tay YC, Todd PA, Rosshaug PS, Chou LM. 2012. Simulating the transport of broadcast coral larvae among the Southern Islands of Singapore. Aquat Biol 15: 283-297

Tomascik T, Mah AJ, Nontji A, Moosa MK. 1997. The ecology of the Indonesian Seas. Part One. Periplus, Hongkong.

Treml EA, Halpin PN, Urban DL, Pratson LF. 2008. Modeling population connectivity by ocean currents, a graph-theoretic approach for marine conservation. Landsch Ecol 23: 19-36.

van der Meer MH, Berumen ML, Hobbs JPA, van Herwerden L. 2015. Population connectivity and the effectiveness of marine protected areas to protect vulnerable, exploited and endemic coral reef fishes at an endemic hotspot. Coral Reefs 34: 393-402. DOI: 10.1007/s00338014-1242-2.

Vermeij MJA, Fogarty ND, Miller MW. 2006. Pelagic conditions affect larval behavior, survival, and settlement patterns in the Carribean coral Montastraea faveolata. Mar Ecol Prog Ser 310: 119-128.

Wijayanti DP, Indrayanti E, Nuryadi H, Rintiantono SA and Sabdono A. 2018. DNA barcode of Acropora hyacinthus of Karimunjawa Archipelago. IOP Conf Ser: Earth Environ Sci 139: 012017. doi:10.1088/1755-1315/139/1/012017.

Wijayanti DP, Indrayanti E, Wirasatriya A, Haryanto A, Haryanti D, Sembiring A, Fajrianzah TA, Bhagooli R .2019. Reproductive Seasonality of Coral Assemblages in the Karimunjawa Archipelago, Indonesia. Front Mar Sci 6: 195. DOI: 10.3389/fmars.2019.00195.

Wood S, Paris CB, Ridgwell A, Hendy EJ. 2014. Modelling dispersal and connectivity of broadcast spawning corals at the global scale. Glob Ecol Biogeogr 23: 1-11. 